\title{
JAあいち経済連における農薬の安全使用に向けた取り組み
}

\author{
永井雄太郎 ${ }^{1, *}$, 原 広 ${ }^{2}$ \\ ${ }^{1} \mathrm{JA}$ あいち経済連営農支援センター \\ ${ }^{2} J A$ あち経済連営農総合室
}

（2015年12月 7 日受理）

\section{Efforts to safety use of pesticides in JA Aichi Keizairen}

\author{
Yutaro NAGAI ${ }^{1}$ and Hiroshi Hara ${ }^{2}$ \\ ${ }^{1}$ Agriculture Support Center, JA Aichi Keizairen, 115 Shinshinden, Sugiyama-cho, Toyohashi-shi, Aichi 441-3302, Japan \\ ${ }^{2}$ Einosogo-shitsu, JA Aichi Keizairen, 3-3-8 Nishiki, Naka-ku, Nagoya-shi, Aichi 460-0003, Japan
}

Keywords: pesticide, residual analysis, GAP, traceability, safety and security of food, risk management.

\section{はじめに}

JA あいち経済連は, 経営理念 ${ }^{1)}$ の中に「実需者・消費者 に対する愛知県産農畜産物の安全・安心・新鮮の提供」をめ ざすことを掲げている，この理念の実現のため，本会を含む JAグループ愛知では,「結果管理」である残留農薬分析と, 「工程管理」である生産履歴記帳や GAPに取り組んでおり, これらの管理手法を組み合わせることにより, 取り扱う農作 物の効率的な安全・安心確保に努めている.

本稿では,「農薬の不適切な使用を減らすことで, JAグ ループ愛知が取り扱う農産物のさらなる安全を確保し, 消費 者からの信頼を高める」という目的を達成するために, どの ような分析を行い，その結果をどう活用しているのかといっ た点を中心として, 取り組みの概要について説明する.

\section{1. 愛知県農業の特徵と JA あいち経済連の役割}

愛知県と言えば, 全国的には自動車産業を中心とした工業 県としてのイメージが強いが, 一年を通じて比較的温暖な気

\footnotetext{
* 干 441-3302 愛知県豊橋市杉山町字新々田115

E-mail: y-nagai@ja-aichi.or.jp

(C) 日本農薬学会
}

候と, 豊かな水資源に恵まれ, 農業産出額全国第7位（平成 25 年度）の農業県としての顔も持つ. 園芸作物の栽培が盛 んであり, 出荷額に占める野菜や花の割合が高いことが, 愛 知県農業の特徵である. 全国一位の産出額を誇るキャベツの 露地栽培をはじめ, ビニールハウスなどを活用した花や大葉 などの施設栽培が盛んに行われている. 大葉を含むつまも の, いちじく, ぎんなん等のマイナー作物の生産量が多いこ ととも特徵の一つである，また，大消費地である名古屋市を 擁し, 直売所での野菜・果実などの販売が多く, 多岐にわた る農作物が栽培されている.

JA あいち経済連は, 県下のJA（農協）が会員となって設 立された県段階の連合組織である. 県下生産者への, 肥料・ 農薬・農業機械などの生産資材の供給・生産指導を通じて, 安全・安心で良質な農産物の生産支援を行うとともに, 生産 された農産物の市場・量販店・加工業者などへの販売を行っ ている.

\section{JA グループ愛知の安全・安心対策}

\section{1. 工程管理と結果管理}

図 1 に工程管理である生産履歴記帳と結果管理である残留 農薬検查の長所短所をまとめた。

JA あいち経済連では, 豊橋市に設置した営農支援セン 


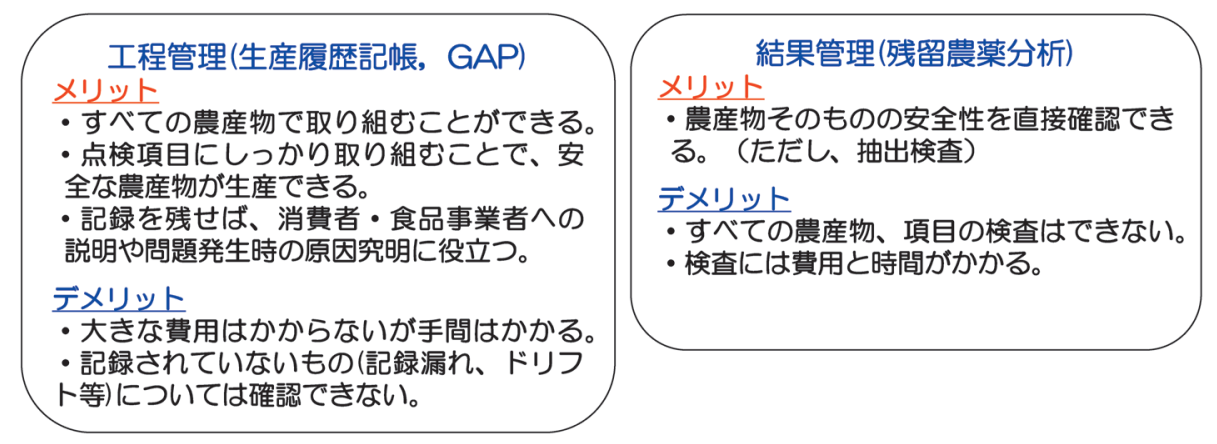

図1. 工程管理と結果管理.

ターにおいて, JAグループ愛知で取り扱う農作物を対象に, 残留農薬自主検査を実施している．外部委託分も含め年間 約 3,000点の分析を行っており，これは都道府県レベルでみ ればかなり多い方である。この検査で適用外農薬が検出され たり，残留基準值の超過のおそれがあると判断された農作 物については，ルールに基づいて出荷停止等の適切な対応を 行っている. しかし, 残留農薬検査は, 出荷物からの抽出検 查であり，大部分の農作物は検査を受けないまま出荷され る.そのため, 検査をしていない農作物に問題があっても出 荷を止めることはできない，すべての出荷物について，残 留する可能性のあるす心゙ての農薬を分析することができれ ば，この問題は扔沶むね回避できるが，そのコストは莫大な ものになる．農林水産省や厚生労㗢省の残留農薬に関する 調査結果 ${ }^{2,3)}$ は, 現状, 農薬がおおむね適正に使用されてお り，わずかにある基準值超過事例も含め，健康に影響を及ぼ すレベルの残留は認められていないことを示している．残留 農薬は，もともと安全側に十分な余裕をもって規制されてお $\eta^{4-6)}$ ，実態的にもリスクが十分小さいレ心゙ルで管理されて いることを考えれば，全数検査を実施したとしてもコストに 対して健康影響リスクを低減させる効果は，ほとんど期待で きない。

一方，「工程管理」である生産履歴記帳では，生産工程を 記録し，その記録から，すべての出荷物で適切に農薬が使用 されているかどうかを確認することができる．農薬の使用基 準は，それに従って農薬を使用すれば，収穫物に残留する農 薬が基準值を超過することがないように設定されている。そ のため, 生産履歴により適切な農薬の使用が確認できれば, 少なくとも実際に散布された農薬に関しては収穫物に基準值 を超えて残留することはないと考えられる。しかし，これは 記帳が正確にされているということが前提であり，記帳が間 違っていたり，記入漏れがある場合には確認ができない。ま た，洗浄不足やドリフト等非意図的な原因で発生する污染に ついては，記帳は無力である。そのような場合には，検査し た検体に残留する農薬を直接検出することができる残留農薬 分析が，有効な確認方法になる。
したがって, 生産履歴記帳による全出荷物の管理を主体と し，その短所を残留農薬分析が補うことで，安全安心対策の 取り組みが実効性を増すと考えられる。具体的には, 「検查 結果と生産履歴を照合して, 生産履歷が正しく記録されてい るのかを確認する」,「基準值超過や適用外農薬の検出等の問 題があった場合に，原因究明を行い，同様の原因で問題が発 生しないよう, 再発防止対策を行う」等の対応を通じて, す べての生産者に，「正しく農薬を使用し，正確に記録する」 という意識を持ってもらうことが重要である，それが，農薬 の不適切な使用を減らし, 消費者から信頼される産地づくり につながると考えられる。

\section{2. 生産履歴記帳}

個々の生産者が, 施肥や防除などについて, いつ・どこ で・どのような作業を・どのように・どの程度（使用量な ど）行ったかを具体的に記録し，その内容が生産基準に適合 しているかをJAが出荷前に確認する取り組みである．現在， JAグループ愛知の販売事業で取り扱うすべての品目につい て, 出荷時に生産履歴の提出を義務づけている. OCR記帳 シートを利用した“生産履歴管理システム”の導入により, 生産基準への適合の判断を瞬時に行うことができ，また，生 産履歴情報をデータベース化することで, 取引先や消費者か らの問い合わせに，迅速に回答することができる体制を整え ている.

\section{3. 残留農薬自主検查}

JA あいち経済連は, 1999年度から残留農薬分析事業を 開始しており，現在では年間 3,000 点程の分析を行ってい る(図2). 年間 100 点程度, 定量分析も行っているが, 分 析点数のほとんどは, 自主検査としての一斉分析である. 一斉分析には, ガスクロマトグラフタンデム質量分析計 （GC-MS/MS）および液体クロマトグラフタンデム質量分析 計（LC-MS/MS）を用いている（図3）。平成27年度は 328 成分を分析項目としており，毎年新規剂を中心に追加してい る. 検体を作物別にみると, 果樹, 野菜が $86.1 \%$ と大半を占 
め，米麦大豆は $9.0 \%$ と少ない（図4). 販売区分別でみると， 直売所の割合が $45.1 \%$ と高い（図 5)。

愛知県は施設園芸が盛んであり, また, 冬場でもキャべ ッ, ブロッコリー等の露地野菜が生産されていることから, 年間を通じて検体が途切れることがない，自主検查をできる だけ効率的に実施するため，県下の各JAから年間分析計画 を提出してもらい，それを基に，検体数や搬入時期の調整を 行い，全体の年間分析計画を作成している．検体数の平準 化に努めているが，それでも多い月と少ない月とでは検体数 に2倍以上の開きがある，試料調製にはQuEChERS法を採 用している. QuEChERS法は, 分析対象成分が広く, 迅速 な方法であり, 迅速性を要求される自主検査に適した方法 である ${ }^{7)}$. QuEChERS法では, より効率が高く経済的な分

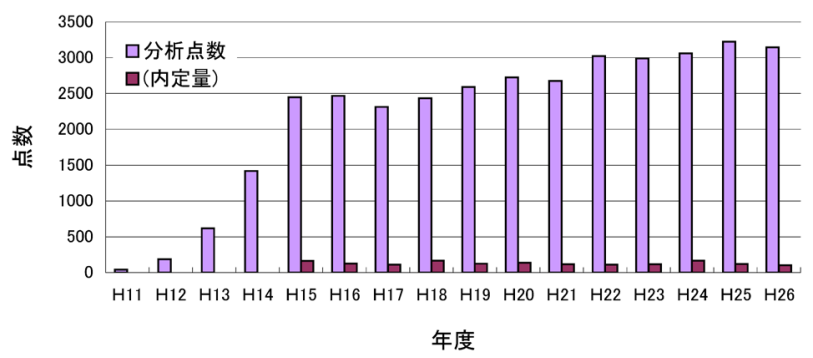

図2. 残留農薬分析点数の年度別推移.

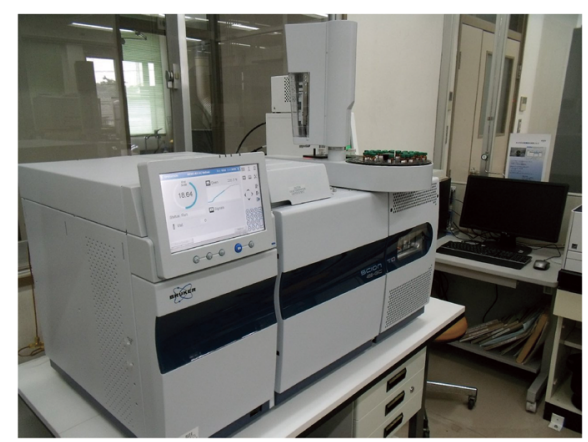

GC-MS/MS Scion ${ }^{\mathrm{TM}} \mathrm{TQ}$ (ブルカー) 散固相抽出（dispersive solid phase extraction: d-SPE）が用 いられており, 特長の一つとなっているが, d-SPEは, ミニ カラム精製と比較すると精製が不十分になる。その悪影響 を回避するため, QuEChERS法では, 選択性および感度の 高い分析装置である GC-MS (/MS), LC-MS/MS の使用が前 提となっている. しかし, GC-MS (/MS) 測定では, 夾雑 物でライナーやカラムが污染され, 長期間安定した測定がで きない, 我々は, 導入に大量注入口装置 (LVI-S200, アイ スティサイエンス）を用いて高沸点夾雑物をライナーに残す ことで, 注入口から先の污染を防いでいる. また, ライナー に残った夾雑成分による影響を防ぐため Analyte Protectants $(\mathrm{APs})^{8)}$ を用いている. APsを用いることで, ライナーが污 染した状態でも測定が可能となる．APsの添加により悪影響 を受ける化合物もあったが，それらについてはLC-MS/MS で測定するようにしている。なお，以前の装置ではトランス ファーラインカラムの先端部がコールドスポットとなり, そ の部分が污染して分離が悪化したため, 月に 12 回, 真空 を解除しての保守が必要であった。しかし, 新しく導入した 装置は, トランスファーラインカラムの先端まで温度がかか るようになっているため, 污染の頻度が大きく低下し, 長 期間保守をせずに使用することができるようになっている. LC-MS/MSでは, マトリックスによる影響（特にイオン化 抑制）を防ぐため, 試料を希釈し, 装置へのマトリックス負

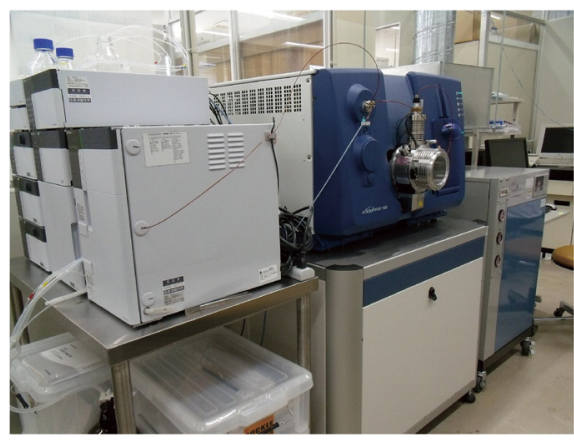

LC-MS/MS QTRAP ${ }^{\circledR 5500(\text { Sciex) }}$

図3. 残留農薬分析装置.

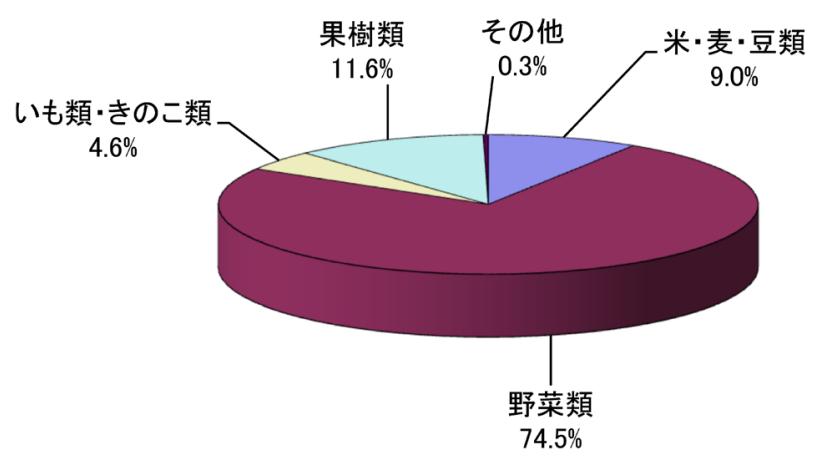

図4. 作目別内訳（平成26年度).

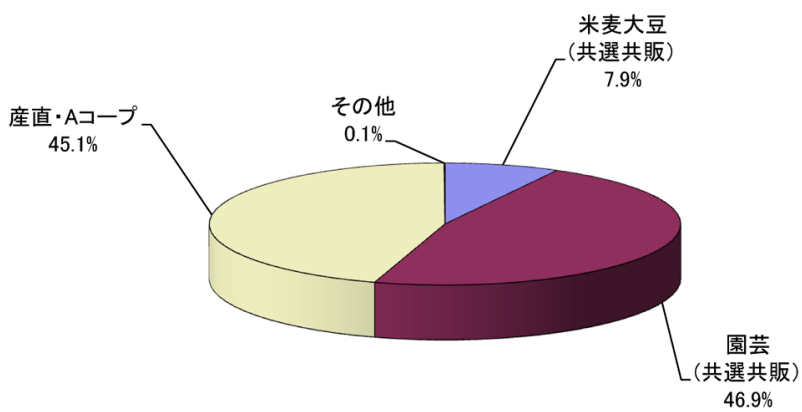

図5. 販売区分別内訳 (平成26年度). 
$5 p p b$ 標準溶液1 $\mu$ l注入

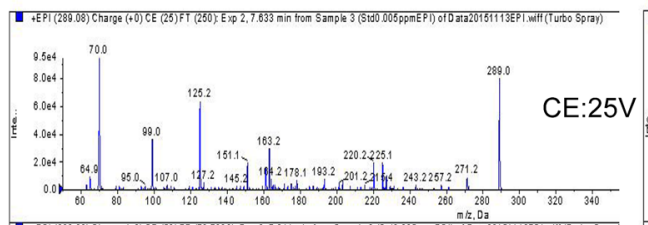

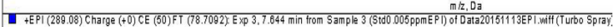
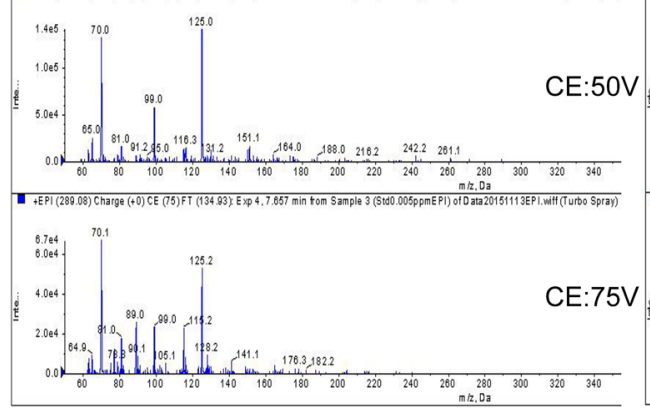

5 倍希橎試料 $1 \mu$ l注入

（一律基準值付近 : 試料液中濃度約2ppb）

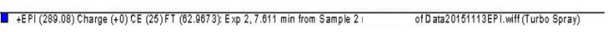

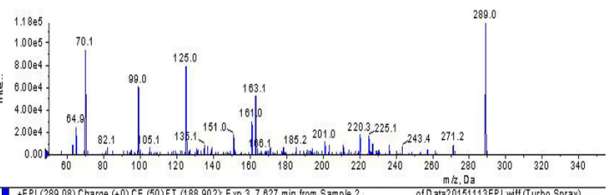

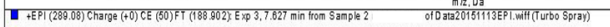
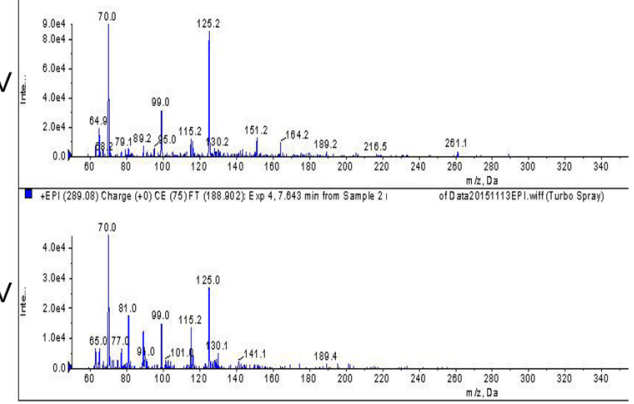

図6. ミクロブタニルの LC - MS/MS スペクトル.

CEの異なる，3つのスペクトルを同時に測定.

荷量を低減している.

問題がある農薬が検出された場合, MRMチャネル数を 増やして測定するとともに，GC-MSスペクトルあるいは LC-MS/MS スペクトルを測定し，定性を行っている．現在 使用しているLC-MS/MS QTRAP ${ }^{\circledR} 5500$ は，イオントラッ プ機能を有しスペクトル測定時の感度が高いため, 以前の 装置では濃縮が必要であった試料でも，そのままで明瞭な LC-MS/MSスペクトル（図6）が得られ，使い勝手がよい. そのほか, GC-MS/MS, LC-MS/MS両方で確認するなどの方 法を用いる場合もある. 基準值超過の判断には, 標準添加法 を用いる. 同じ種類の作物であっても試料ごとにマトリック スの影響が異なる可能性があることから, 現状では, 標準添 加法が，マトリックスの影響を回避する最も現実的な選択肢 だと考えている.

日常的には，すべての検体に内部標準物質を添加し，その 回収率を確認することで, 試料調製から測定, 解析までの手 順に問題がないことを確認している。内部標準物質には国内 登録がなく分析対象としていない農薬を用いている。また， 毎年, FAPASやJAグループの外部技能試験 ${ }^{7)}$ に参加し, こ れまで継続して良好な結果が得られていることから, 現状, 分析手法や装置, 標準品等の管理方法に大きな問題はないも のと考えている.

\section{4. 分析対象農薬の選定にあたって}

一斉分析の分析対象農薬には, 残留基準值が代謝物を含ん で設定されているもので, 何らかの理由で親化合物だけしか 測定できないものも入れてある。この場合, 基準值への適合 を証明することはできない。しかし，不適切な農薬使用の有
無を確認するという観点に立てば，親化合物だけでも測定で きた方が望ましいし，親化合物だけで基準值を超えているよ うなケースであれば，食品衛生法的にも十分に意味がある. 同様に, 回収率が低い農薬であっても, ある程度安定して回 収できるものであれば，定性的な分析対象になりうる。これ も, 農薬の不適切な使用を見つけるための手段として, 有効 だと考えている（必要に応じて定量的に分析できることが望 ましい)，このように問題がないことを証明するための分析 と問題を見つけるための分析とでは, 要件が同じではない. 我々の自主検査の目的には, 問題を見つけるための分析の方 が適していると考えられる.

\section{5. 分析結果報告書の作成，報告}

分析結果報告書（図7）には, 検出成分や検出濃度だけで なく, 代表的商品名, 分析対象作物への適用の有無, 残留基 準值等を記載しており，この報告書を見るだけで農薬取締法 や食品衛生法に対する違反の可能性（=問題あり）が確認で きるようになっている. 適用の有無と残留基準值は, 変わる 可能性があるため, 報告書作成の都度確認をしている. 分析 がスムーズに進行し, 分析結果に問題のない場合には, 検体 搬入日を含め3〜 営業日で報告書を発行することができる. 問題なしの報告書は，依頼元のJAに郵送し，JAの担当者が, 分析結果と生産履歴との照合を行う.

\section{6. 問題あり案件に対する対応}

基準值超過や適用外農薬が検出されるなど, 自主検査の結 果に問題があった場合は, JAグループ愛知 農畜産物の安 全安心対策本部（以下，対策本部）が定めた「残留農薬の検 
残留農薬分析結果報告書（一斉分析用）

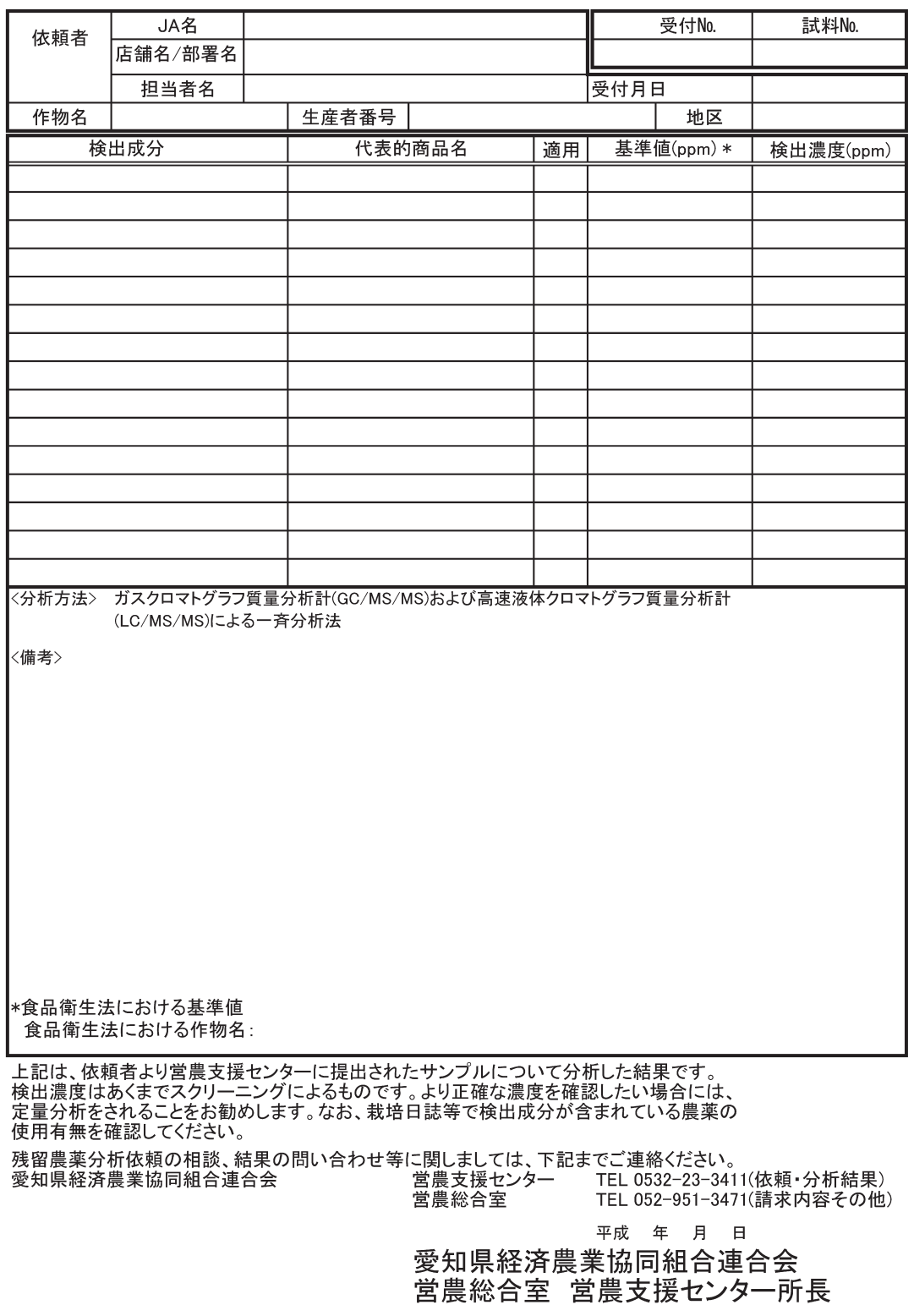

図7. 残留農薬分析結果報告書 (一斉分析用).

出にかかる対応指針（以下，対応指針）」に基づいて適切に 対処している. 対応指針の対応フローの例を図 8 に示した. 対応フローは, (1)行政検査などによるもの, (2)残留基準值超 過（取引先検査および自主検査）, (3)適用外農薬の検出（取 引先検査および自主検査), (4)記帳点検によるもの, の4区 分に対して，それぞれ出荷停止・回収・報告等にルールが記 されている.

\section{7. 問題あり案件に対する原因究明と対処報告}

問題あり案件については，前述の対応フローに基づいて対 処するとともに，「残留農薬にかかる危機発生対処報告書」 により，JAから対策本部にその対処報告を行うよう定めて
いる（図9）. 対処報告書には当該作物の生産履歴記帳シー トを添付するとともに, 問題の発生原因を記入し, それがド リフト, 防除器具の洗浄不足, 土壌残留の場合は, その根拠 となる写真や生産履歴シート（前作や周辺作物）等を添付す るよう定めており, 発生原因を正確に把握できるようになっ ている.

\section{8. 再発防止指導}

対策本部は，対処報告書に基づいて県下全体の問題あり 案件の発生原因を把握し, 発生傾向の解析を行う。その結 果を, 各JAや生産部会での講習会, JAの担当者を集めた 「安全安心対策担当者会議」等の機会を利用してJA・産地に 


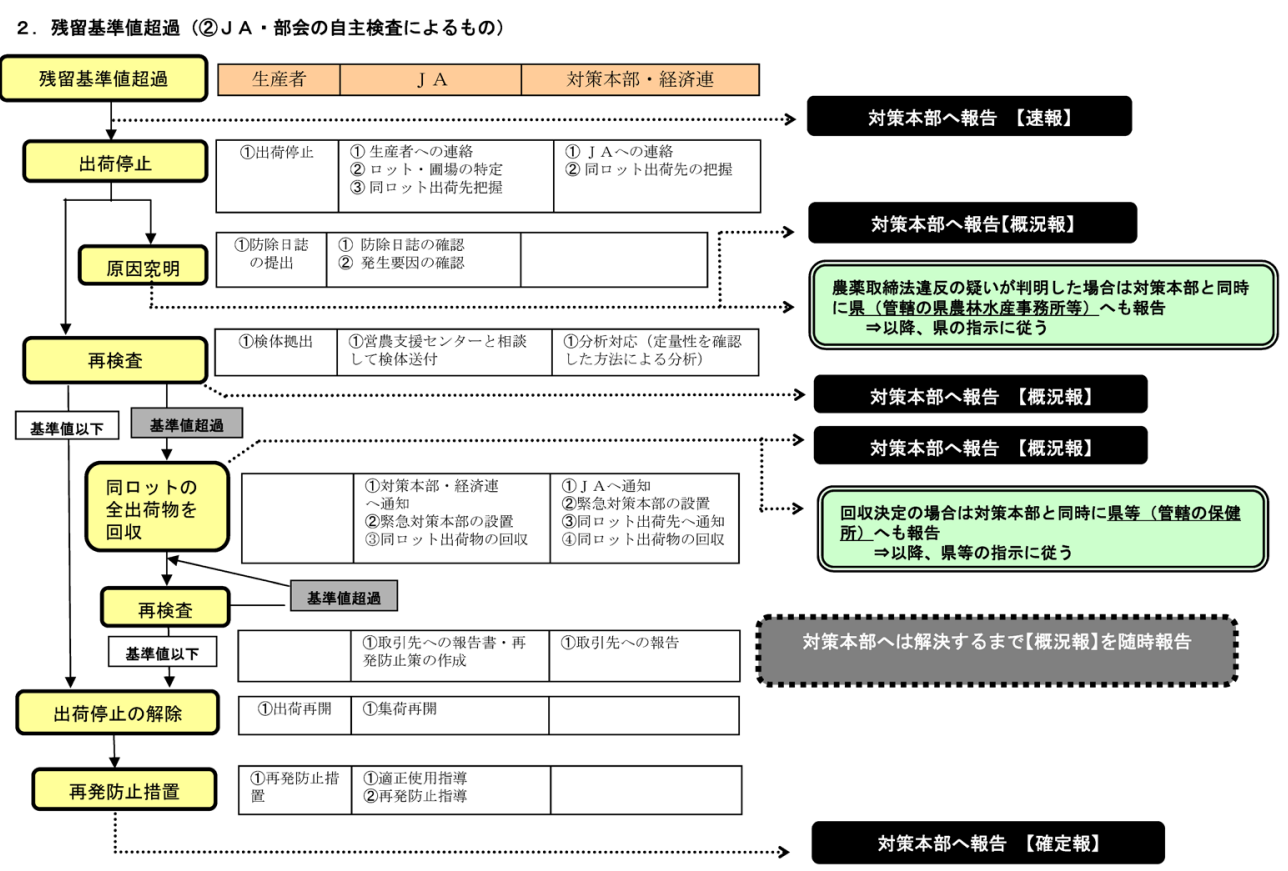

図 8. 「残留農薬の検出にかかる対応指針」より対応フロー（抜粋：JA愛知中央会, 2011）.

フィードバックすることで，再発防止に努めている．また， 農薬取締法違反の疑いが判明した場合は愛知県農林水産部に 報告し，県から個別に指導を受ける体制も整えている。

\section{3. 今後の安全安心対策}

残留農薬に関しては，生産現場で農薬が適切に使用されて いる状態を維持することが安全を確保するうえで重要であ る．現在の取り組みを続けることで，使用基準の順守，散布 器具洗浄やドリフト防止対策の徹底を図っていきたい。 た，これまでは，問題あり案件を基に再発防止指導を行って きたが，潜在的な問題を検出することで，よりきめ細かな指 導につなげることができると考え，昨年度から，問題のない 検体についても，す心゙ての検出農薬をデータベース化し，解 析を行っている. 今後, この解析結果を指導に活用していき たいと考えている。

これまで，農作物の安全・安心というと残留農薬が取り上 げられることが多かったが，安全・安心に関わる課題は残留 農薬だけではない。JAグループ愛知では，消費者に不快感 を与え物理的な危害要因にもなりうる異物混入や，実際に 健康被害が出るおそれがある病原性微生物による污染を防 ぎ，加えて環境保護や作業者の安全確保のため，農業生産工 程管理「GAP (Good Agricultural Practice)」を推進してい る. GAPでは, 農業生産活動を行ううえで必要な点検項目 をチェックリスト化し，それに従って各工程の実施や記録， 点検および評価を行う.

\section{4. 消費者に「安心」を提供できているのか？}

\section{1. アンケート調査結果から見た残留農薬に対する消費} 者のリスク認識

ポジティブリスト制度の施行により, 施行以前に比べ残留 農薬に対する法的な規制は格段に厳しくなっている。また， JAグループ内でも，多くの産地が自前の検査施設を持ち， 自主検査を行うことで, 安全な農作物の出荷に取り組んでき ている ${ }^{7,9)}$.リスク評価，リスク管理がともに機能すること で, 残留農薬に関しては, 健康被害が起こるリスクが低く安 全な状態を達成できていると考えられるが，そのことで消費 者の残留農薬に対する安心感は高まっているのであろうか? 2014年度に, 内閣府食品安全委員会が実施した「食品に係 わるリスク認識アンケート調査」の結果 ${ }^{10)}$ を見ると，「健康 への影響に気を付けるべきと考える項目」として，一般消費 者は，農薬の残留をO-157等の病原性微生物に次いで上位 にあげている，一方，食品安全の専門家は，病原性微生物は 上位にあげているものの, 農薬の残留についてはリスクを低 く評価しており，一般消費者との間でリスク認識に乘離が見 られる。逆に, タバコ, 偏食や過食, アレルギー, 飲酒等の ように，専門家がリスクを高く評価し，一般消費者が低く評 価している項目もあり，両者のリスク認識にはかなりの違い がみられる。

2010年度に内閣府政府広報室が実施した「身近にある化 学物質に関する世論調査」 ${ }^{11)}$ では, $67 \%$ の人が化学物質に は「不安のあるものが多い」と回答しており, 安全性に不安 がある化学物質として, 農薬・殺虫剤・防虫剂をあげた人の 
残留農薬にかかる危機発生対処報告書

JAグループ愛知 農畜産物の安全・安心対策本部御中

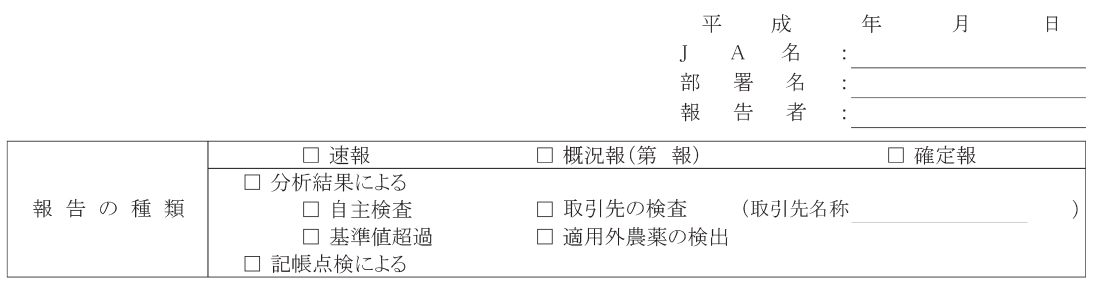

\begin{tabular}{|c|c|c|c|c|c|}
\hline 発 生 日 時 & 平成 & 年 & 月 & 日 & ) \\
\hline 発 生 場 所 & JA & & & 部会·店舖 & \\
\hline 氏名またはグループ & & & & & \\
\hline 現地調査 & 調査月日： & 月 & 日 & 調査者： & \\
\hline
\end{tabular}

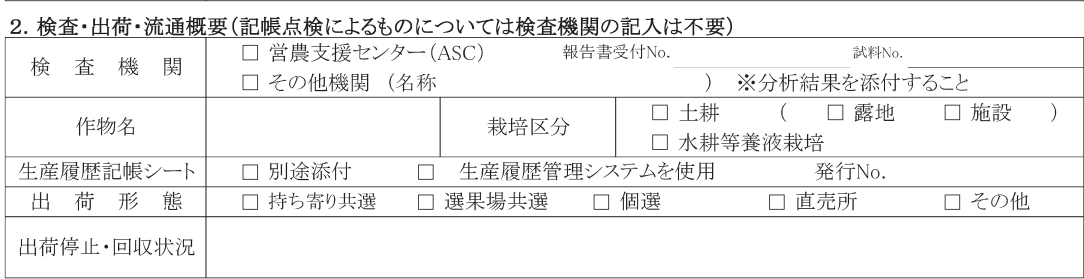

3. 検出状況·違反区分·発生原因 (2成分以上検出の場合は別紙使用)

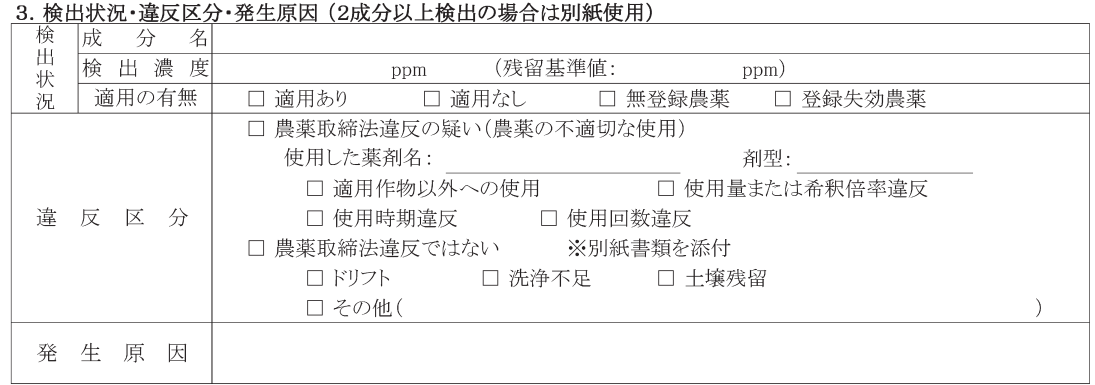

4. 今後の対応策
\begin{tabular}{|c|c|}
\hline $\begin{array}{c}\text { 安全確保の } \\
\text { 措置状況 } \\
\text { (対策会議、出荷自肃、 } \\
\text { 再検查等) }\end{array}$ & \\
\hline 再 発 防 止 対 策 & \\
\hline 特 記 事 項 & \\
\hline
\end{tabular}

\footnotetext{
【添付書類】

年有履歴記帳シート

○ドリフトの場 合:原因となった生産者の生産履歴記帳シートのコピーおよびほ場周辺の写真

洗 浄 不足 の場 合:原因となった農薬の使用実態(対象作物、希釈倍率)と洗浄方法

土 鎄 残 留の場 合:原因となった過去の生産履歴記帳シートのコピーもしくは農薬使用記録 (土壤の残留農薬分析結果でも可)
}

図9. 残留農薬にかかる危機発生対処報告書（JA 愛知中央会, 2011).

数が最も多いという結果になっている.

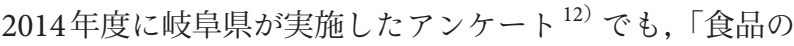
安全性についてあなたが不安に思うことはありますか？」と いう質問に対して，74.5\%の人が残留農薬をあげている。

これらアンケートの結果だけでは, 一般の人々の残留農薬 についてのリスク認識が, 改善傾向にあるのかどうかは判断 できないが, 少なくとも, 一般の人々の多くが残留農薬に対 して不安を抱いていることがわかる。

\section{2.「安心」を提供するためにはどうしたらいいのか}

「安全.でも，安心できない...」.これは, リスク心理学の 専門家である中谷内の著書 ${ }^{13)}$ のタイトルであるが，現在の
残留農薬がおかれた状況を表している，中谷内は，この本の 中で,「安全は安心のための必要条件ではあるが十分条件で はない」,「人びとが生活のさまざまな局面で安心して暮らす ために必要なのは, それぞれの局面でのリスク管理にたずさ わる人や組織への信頼である」ことを指摘している。この考 え方に当てはめれば，残留農薬に関するリスク管理に携わる 人や組織への信頼が得られていないということになる. 前 述の食品安全委員会のアンケート ${ }^{10)}$ で，一般消費者の $29 \%$ が, 農薬の残留をがんの原因の一つとして考えているが, こ の結果は, 発がん性に関するもの ${ }^{14,15)}$ も含め, そもそも農 薬のリスク評価やリスク管理の仕組みが信頼されていないこ と（「知らないけれど信頼できない」を含む）を示している 
のではないだろうか.

もし，そうだとすれば，生産者サイドの安全安心確保のた めの取り組みだけでは, 消費者に安心してもらうことは困難

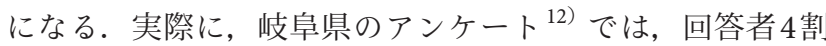
弱が農薬を使って作られた農作物に不安を感じていると回答 し，その大部分が不安を感じる理由として，「残留農薬の人 体への影響が不安」,「農薬の規制制度がどうなっているか知 らない」ことを選択している.

加工食品への農薬混入事件が相次いで発生したことで，も ともとよくない農薬のイメージがさらに悪化した可能性もあ るが，個人的には，食品衛生法に基づく厳格なリスク管理の 手法も，かえって不安をあおる原因の一つになっているので はないかと懸念している．農作物から残留基準を超過して農 薬が検出された場合，それが一律基準值をわずかに超過した ものであっても, 回収するということを繰り返している. 残 留基準を，それを超えれば何らかの健康影響があると考えて いる消費者からすれば，基準值超過の報道に接するたび，農 作物のリスク管理に不信感を募らせることになるのではない だろうか？ 英国では，最大残留基準值を超過した場合，曝 露量評価を行い, 摂取量が急性参照用量（ARfD）を超える と確認されてから回収措置等の対象になるということであ る $^{6,16)}$. 本誌等でも, 度々言及されているが ${ }^{16-19)}$, 今後, 我 が国においても ARfDが整備されれば ${ }^{20)}$ ，基準值超過が発生 しても，ARfDを使うことで適切にリスクを評価することが 可能となる. その結果に基づいて科学的に整合性のとれた対 応ができるようになることを期待している．また，分析結果 に対してリスク評価を行うことで, 技術的な解決が困難な後 作物残留も，健康リスクのないものについては解決すること ができるものと考えられる，当然，健康リスクがないと判断 される場合でも，原因究明と生産者の指導はしっかりと行う 必要がある.

ただ，この対応だけで消費者の信頼が得られるとは思わな い. 例えば，国や行政が無農薬，減農薬栽培を推進すること が，「国はやはり，残留農薬は人の健康に悪影響を及ぼして いると判断している」というメッセージだと捉えられること があるようである ${ }^{21)}$.

信頼が得られない原因がどこにあり，どう対処すればいい のかは, リスク心理学の知見も取り入れて, 関係者が協力し て探っていくべき課題であると思われる.

\section{おわりに}

農薬のリスク評価とリスク管理の仕組み, その結果として 達成されているリスクが低い現在の状況を消費者に十分理解 してもらい，そのうえで安心してもらうことができれば，理 想的なのであろう。これまでにも農薬の安全性についての リスクコミュニケーションには，いろいろな団体が取り組ん できている ${ }^{22-26)}$ 。しかし，農薬登録制度や基準值設定の手
順 ${ }^{27)}$ は複雑であり，概要を理解してもらうだけでも容易で はないと思われる. また, もし理解しても, 完全なゼロリス クではないことで，不安が払拭されない可能性もある.

前述の仲谷内は，「リスク管理によって安心がもたらされ るとしたら，それはむしろ安全とか危険とかという側面に ついて何も意識しなくなることであろう」と言っている ${ }^{13)}$. 今, 我々にできることは, 安全安心対策を通じて残留農薬の 問題事例を減らし, 消費者が意識せずにすむ状況を作ること なのかもしれない.

なお，本稿は「JAあいち経済連における残留農薬分析の 取組」 ${ }^{28 ）}$ の内容を基に, 最新の情報やその後の状況の変化 等を踏まえて改稿したものである.

\section{引用 文 献}

1) JA あいち経済連 : 経営理念 http://www.ja-aichi.or.jp/main/about/ philosophy/(平成27年11月29日閲覧)

2）農林水産省：残留農薬モニタリング国内産農産物における農薬 の使用状況および残留状況調査結果について http://www.maff. go.jp/j/nouyaku/n_monitor.html（平成27年11月29日閲覧）

3）厚生労働省：食品中の残留農薬調査 http://www.mhlw.go.jp/stf/ seisakunitsuite/bunya/kenkou_iryou/shokuhin/zanryu/index. $h t m l$ (平成27年 11 月 29 日閲覧）

4）内田又左衛門：農薬の今 農薬は安全か? FOOCOM.NET, 2011. http://www.foocom.net/column/ps/3778/(平成27年11月29日閲覧)

5）内田又左衛門：農薬の今 リスクのものさし, FOOCOM.NET, 2011. http://www.foocom.net/column/ps/4743/(平成27年11月 29日閲覧）

6）畧山智香子：ほ九とうの「食の安全」を考えるゼロリスクとい う幻想, 化学同人, 2009.

7) 島村裕二：農薬誌 40, 208-214 (2015).

8）永井雄太郎：食衛誌 51, J-193-J-200 (2010).

9）島村裕二：食衛誌 54, J-313-J-318 (2013).

10）内閣府食品安全委員会 : 食品に係わるリスク認識アンケート調査 の結果について https://www.fsc.go.jp/osirase/risk_questionnaire. data/risk_questionnaire_20150513.pdf（平成27年11月29日閲覧）

11）内閣府政府広報室：身近にある化学物質に関する世論調査の概要 http://www.env.go.jp/press/files/jp/16124.pdf（平成27年11月30 日閲覧）

12）岐阜県：食の安全性に関するアンケート調査結果 https://www. pref.gifu.lg.jp/kensei/koho-kocho/iken-teian/11103/monitoranketo.data/20140307seikatueisei.pdf（平成27年11月29日閲覧）

13) 中谷内一也: 安全. でも, 安心できない… 一信頼をめぐる心理 学, ちくま新書, 2008.

14）農薬工業会：教えて！農薬Q\&A そのまま食べても大丈夫? http://www.jcpa.or.jp/qa/a2_01.html（平成27年11月29日閲覧）

15）三森国敏：発がん性がある化学物質を含む食品の安全性について https://www.fsc.go.jp/monitor/moni_25/moni25-shiryo1-2-tokyo3. pdf（平成27年 11 月 29 日閲覧）

16）畧山智香子：うねやま研究室 日欧比較で分る残留農薬基準値超 えによる回収の愚行, FOOCOM.NET, 2008. http://www.foocom. net/fs/uneyama/2500/(平成27年 11 月 29 日閲覧) 
17) 斎藤 勲：新・斎藤くんの残留農薬分析 ADI と ARfD の対 応ミス1, FOOCOM.NET, 2011. http://www.foocom.net/column/ residue/1814/(平成27年11月29日閲覧)

18）鈴木勝士：農薬誌 38, 175-184 (2013).

19) 星野敏明：農薬誌 39, 202-210 (2015).

20）厚生労働省：急性参照容量（ARfD）を考慮した食品中の残留農 薬基準の設定について http://www.mhlw.go.jp/file/05-Shingikai11121000-Iyakushokuhinkyoku-Soumuka/0000040985.pdf (平成 27 年 11 月 29 日閲覧)

21）農薬学会；農薬Q\&A質問 18 http://pssj2.jp/overview/Q\&A.html (平成 27 年 11 月 29 日閲覧）

22）岐阜県：平成 21 年度食品の安全安心シンポジウム http://www. pref.gifu.lg.jp/kurashi/shoku/shokuhin/11222/simpojiumu.html （平成27年 11 月 29 日閲覧）

23）コープネット事業連：農薬の使用について http://www.coopnet. jp/work/shouhin_seisaku/nouyaku.php（平成27年11月30日閲 覧）

24）農林水産省他：食品に関するリスクコミュニケーション一知ろ う，考えよう，農薬のこと一（9月16日東京都千代田区）http:// www.maff.go.jp/j/syouan/johokan/risk_comm/r_kekka_nouyaku/ $\mathrm{h} 260916 . \mathrm{html}$ (平成 27 年 11 月 29 日閲覧)
25）農林水産省他：「食品に関するリスクコミュニケーション一知ろ う, 考えょう, 農薬のこと一」の開催および参加者の募集につ いて http://www.maff.go.jp/j/press/syouan/johokan/150916.html (平成27年 11 月 29 日閲覧)

26）東海コープ事業連：おしらせ「農薬のリスク」について学ぶシン ポジウムを開催しました. http://www2.tcoop.or.jp/information/ b79ln3000000421o.html（平成27年 11月29日閲覧）

27）農林水産省：農薬の基礎知識詳細 http://www.maff.go.jp/j/ nouyaku/n_tisiki/tisiki.html\#kiso4_1（平成27年11月29日閲覧）

28) 原 広志：植物防疫 66, 55-60 (2012). 